\title{
Pembentukan Peta Kognitif Tunagrahita Ringan Dalam Penguasaan Konsep Pengukuran Di Bidang Berhitung dan IImu Pengetahuan Alam
}

\author{
Mumpuniarti \\ PLB-FIP-Universitas Negeri Yogyakarta, email: mumpuni@uny.ac.id
}

\begin{abstract}
Abstrak: Penelitian ini dilakukan pada pembelajaran bagi tunagrahita ringan dengan integrasi antara bidang berhitung dan ilmu pengetahuan alam melalui bermain timbangan memakai permainan timbangan neraca. Pembelajaran dengan cara tersebut bertujuan mengembangkan peta kognitif tunagrahita ringan dalam penguasaan konsep ukuran berat dan isi. Pendekatan penelitian menggunakan penelitian tindakan kelas, subjek penelitian 5 siswa tunagrahita ringan kelas 1 SMP Negeri 2 Yogyakarta, monitoring tindakan dengan pedoman observasi terstruktur maupun observasi tidak terstruktur, analisis data dengan kualitatif dari keterangan berupa deskripsi melalui menyeleksi, menyederhanakan, mengklasifikasikan, menfokuskan, dan mengorganisasikan. Hasil penelitian menunjukkan bahwa penguasaan peta konsep pengukuran berat dan isi pada tunagrahita ringan melalui proses bertahap dan secara grouping ketika bermain timbangan. Proses itu mulai mengukur dari benda yang perbedaan ukuran beratnya signifikan secara bertahap perbedaan itu diperkecil sampai ke benda yang perbedaan beratnya tidak signifikan; demikian juga sebaliknya mengukur berat dari isi yang perbedaan volumenya berbeda tetapi jenis bendanya sama sampai volumenya sama tetapi jenisnya berbeda.
\end{abstract}

Kata kunci: peta kognitif, tunagrahita ringan, konsep pengukuran berhitung dan IPA

\begin{abstract}
This research was conducted in the learning for mild mentally retarded with the integration between field arithmetic and science through game play scales using balance scales. Learning in a way that aims to develop of mild mentally retarded cognitive map in mastering the concept of content size and weight; approach to research using classroom action research, research subjects 5 of mild mentally retarded students grade 1 SMP at SLB Negeri 2 Yogyakarta, monitoring actions with a structured observation guide or unstructured observation, analysis qualitative data with a description of the information by selecting, simplifying, classifying, focused, and organized. The results showed that the mastery of the concept maps for weight and content measurement in mild mentally retarded through a gradual process and the grouping when playing scales. The process began measuring the body weight difference significant size difference was gradually reduced until the body weight difference was not significant; vice versa measuring the weight of the contents of the volume difference is different but the same type of object to the same volume but a different kind.
\end{abstract}

Key words: cognitive map, mild mentally retarded, measurement concept in math, and science.

\section{Pendahuluan}

Pembelajaran akademik bagi tunagrahita ringan terutama di bidang matematika khususnya berhitung diarahkan untuk mendukung kemandirian di dalam pekerjaan dan kehidupan sehari-hari. Salah satu substansi bidang matematika bagi tunagrahita ringan ialah kemampuan di dalam pengukuran. Kemampuan ini dapat digunakan untuk bekerja maupun untuk kehidupan sehari-hari. Misalnya, mengukur benda yang akan dibuat keterampilan, mengukur bahan untuk dimasak, dan mengukur benda yang dibeli atau konsumsi sehari-hari sesuai dengan uang yang dimiliki.

Salah satu kemampuan mengukur tersebut terutama untuk mengukur berat dan isi. Kemampuan ukuran berat dan isi adalah kemampuan yang diperlukan untuk menentukan besaran benda dari segi beban atau besarnya benda yang dibutuhkan dalam kehidupan sehari- 
hari. Kebutuhan itu harus disertai kemampuan mengukur dan untuk mengukur kedua konsep tersebut tidak dapat dihubungkan secara otomatis, seperti jika benda yang besarannya lebih banyak pasti yang lebih berat. Penentuan benda yang lebih berat harus diukur menggunakan timbangan, dan pengukurannya menggunakan norma-norma satuan berat.

Norma-norma satuan berat tersebut nantinya sebagai materi pelajaran yang perlu dipelajari siswa tunagrahita ringan. Khususnya dalam keterampilan kehidupan sehari-hari sehingga mampu menimbang sesuai dengan kebutuhan masalah yang harus diatasi. Pembelajaran untuk membimbing siswa tunagrahita ringan memiliki kemampuan menimbang beserta konsep satuansatuan beratnya sangat sulit dilakukan guru. Kesulitan tersebut dikemukakan oleh guru dengan adanya suatu fenomena-fenomena yang terjadi pada siswa tunagrahita bahwa benda yang kelihatan lebih besar atau lebih banyak pasti lebih berat, seperti antara kapas dan besi. Pada kedua benda itu siswa tunagrahita selalu memilih bahwa kapaslah yang lebih berat, karena guru menyajikan kedua benda itu dalam kondisi kapas ditunjukkan jumlahnya yang lebih banyak.

Fenomena tersebut mengindikasikan bahwa siswa tunagrahita selalu melihat secara fakta yang terlihat, belum memiliki suatu pengertian bahwa berat hubungan dengan besar/isi benda tergantung berat jenisnya. Demikian juga, mereka belum memiliki pengertian bahwa untuk penentuan benda yang lebih berat atau keadaan beratnya perlu ditimbang dahulu. Persoalan atau masalah yang dirasakan oleh guru itu, diperlukan suatu penyelesaian dengan mengubah proses pembelajaran yang dilakukan dalam penanaman konsep berat dan isi bagi siswa tunagrahita ringan.

Masalah yang dirasakan oleh guru tersebut diberikan alternatif solusinya. Alternatif yang dipilih guru adalah membuat alat peraga guna pembelajaran yang dapat menjembatani proses perubahan berat. Pengubahan proses tersebut yang mengimplikasikan adanya penelitian tindakan kelas untuk perbaikan dalam proses penguasaan konsep berat dan isi pada siswa tunagrahita ringan.
Diagnosis dari persoalan tersebut, karena penguasaan konsep pengukuran berat yang selanjutnya berimplikasi pada besaran isi bagi tunagrahita ringan merupakan sesuatu yang abstrak dan hubungannya tidak secara langsung. Konsep yang salah sering terjadi pada siswa tunagrahita ringan di SLB Negeri 2 Yogyakarta dalam menduga suatu berat bahwa benda yang lebih besar diduga pasti lebih berat. Konsep yang terjadi demikian berimplikasi kebingungan guru dalam menanamkan konsep pengukuran berat secara benar dengan melalui pembelajaran yang tidak memberatkan proses kognitif siswa tunagrahita. Untuk itu, sebelum siswa melangkah mempelajari konsep berat yang sebenarnya perlu dijembatani dengan konsep nyata dari timbangan dan proses menimbang untuk memastikan sifat berat suatu benda. Diagnosis dari masalah tersebut, siswa belum memiliki jembatan tentang proses perubahan berat suatu benda dan cara menentukan.

Penentuan intervensi terhadap diagnosis dari masalah tersebut atas dasar memberikan jembatan kepada siswa tunagrahita tentang proses perubahan berat dan cara penentuannya atau penaksirannya. Jembatan itu atas dasar harapan guru untuk memberi pelajaran yang menyenangkan dengan tidak memberatkan proses kognitif siswa tunagrahita ringan. Jembatan itu adalah simulasi permainan timbangan. Berdasarkan solusi terhadap diagnosis tersebut, penelitian dirumuskan masalahnya sebagai berikut 1) Bagaimana "Simulasi Permainan Timbangan" dapat memperbaiki penguasaan tunagrahita ringan tentang konsep variasi pengukuran berat dan isi dari berbagai benda?, 2) Apakah "Simulasi Permainan Timbangan" ini efektif untuk pembentukan peta kognitif penguasaan konsep ukuran berat dan isi bagi tunagrahita ringan?

Tujuan penelitian adalah mengetahui perbaikan proses pembelajaran bagi tunagrahita ringan yang memerlukan berpikir kognitif, dan mengetahui cara pembentukan peta kognitif pada tunagrahita ringan dalam penguasaan konsep tentang ukuran berat dan isi dengan menggunakan simulasi permainan timbangan. Manfaat penelitian untuk perbaikan proses pembelajaran matematika dan Ilmu Pengetahuan Alam pada 
tunagrahita ringan. Bagi siswa diperolehnya suatu keterampilan dan pengetahuan cara menimbang untuk menentukan berat benda serta perubahan isinya. Bagi sekolah sebagai sumber informasi untuk kebijakan dalam peningkatan pembelajaran di sekolah.

\section{Kajian Literatur}

\section{Pendekatan Pembelajaran bagi Tunagrahita Ringan}

Penyandang tunagrahita merupakan individu yang memiliki keterbelakangan mental. Menurut AAMR (Association American Mental Retardation) yang dikemukakan oleh Ruth Luckasson melalui (Smith et.al (2002: 50) individu dipandang terbelakang mental jika memenuhi dua kriteria. Pertama memiliki tingkat kecerdasan di bawah rerata dan disertai keterbelakangan adaptasi tingkah laku. Keterbelakangan adaptasi tingkah laku adalah kemampuan penyesuaian diri dibandingkan dengan usia sebaya. Tingkah laku yang dibandingkan itu ialah segala aspek yang meliputi 10 bidang keterampilan adaptif, yaitu: komunikasi, menolong diri sendiri, keterampilan kehidupan di keluarga, keterampilan sosial, kebiasaan di masyarakat, pengarahan diri, menjaga kesehatan dan keamanan diri, akademik fungsional, waktu luang dan kerja .Definisi dari AAMR tersebut yang sekarang menjadi dasar untuk petunjuk atau identifikasi pada individu yang dianggap tunagrahita. Definisi tersebut juga ditandaskan Oliver \& Williams (2006) "The mentally handicapped child has special educational needs and is thus often regarded as special in the sense that he requires assistance and support to overcome cotextual, social and individual difficulties." Keterbatasan kemampuan penyandang tunagrahita tersebut berkaitan dengan layanan pendidikan yang diberikan untuk mereka. Layanan pendidikan yang diberikan dalam rangka optimalisasi kemampuan mereka supaya mampu mandiri di kehidupan masyarakat. Layanan tersebut menyesuaikan dengan kondisi mereka dan prediksi optimalisasi bagi mereka yang akan dicapai juga disesuaikan dengan kondisi mereka.

Salah satu di antara klasifikasi tunagrahita ialah tunagrahita kategori ringan. Anak tunagrahita kategori ringan (mild mentally retarded) adalah anak yang tingkat kecerdasannya
(IQ) berkisar antara 50 sampai dengan 70. Rendahnya tingkat kecerdasan itu juga mengakibatkan terbatasnya perkembangan pencapaian tingkat usia mental mereka. Tingkat pencapaian usia mental/umur kecerdasan mereka setaraf anak usia sekolah dasar kelas enam (umur anak 12 tahun) walaupun sudah mencapai usia dewasa.

Tunagrahita ringan menurut Astati (2001: 57) memiliki karakteristik pertumbuhan fisik seperti anak normal tetapi kesehatan tubuh dan kematangan motorik lebih lemah dibandingkan dengan anak normal yang seusia sebaya; banyak yang lancar berbicara tetapi kurang perbendaharaan kata; mengalami kesulitan berpikir abstrak tetapi mereka masih mampu mempelajari hal-hal yang bersifat akademik secara terbatas. Menurut Inhelder dan Woodward dalam (Smith et al., 2002: 250) perkembangan kognitif tunagrahita ringan melalui tahapan yang sama seperti anak yang tidak retardasi, dengan perbedaan pokok pada pencapaian nilai dan level yang tertinggi. Pencapaian bagi anak yang retardasi akan lebih lambat, dan lebih berat retardasinya, lebih lambat lagi perkembangan tahapannya. Sebagai tambahan, individu yang retardasi tidak mampu mencapai seluruh tahapan perkembangan. Menurut Inhelder, anak-anak yang retardasi ringan hanya mencapai level operasional konkrit. Pencapaian level operasional konkrit itu dicapai oleh tunagrahita pada usia kronologis yang jauh lebih tua. Jadi pada usia 11 tahun anak normal mencapai tahap operasional konkrit, pada tunagrahita ringan tahapan tersebut mungkin dicapai pada usia kronologis 15 tahun atau 17 tahun. Karakteristik tunagrahita di atas dan kemampuan tahap pencapaian perkembangan di bidang kognitif sebagai dasar alternatif pendekatan pembelajaran bagi tunagrahita ringan.

Pembelajaran merupakan proses belajar yang dilakukan individu untuk mencapai sesuatu. Menurut Dimyati \& Mudjiono (2002: 10) program pembelajaran berisi urutan perilaku yang dikehendaki, penguatan, waktu mempelajari perilaku, dan evaluasi. Pembelajaran sebagai proses belajar berorientasi pada hasil dan hasil itu berupa perilaku hasil belajar yang meliputi kapabilitas keterampilan, pengetahuan, sikap, dan 
nilai. Pembelajaran menurut pendapat tersebut sebagai proses belajar adalah menerangkan individu melakukan belajar. Perilaku belajar itu supaya mencapai kapabilitas di berbagai aspek dari individu. Perilaku belajar individu untuk mencapai sesuatu dikaji oleh berbagai teori belajar.

Teori belajar menerangkan apa yang terjadi selama siswa belajar (Soekamto, 1994: 13). Pendapat itu berimplikasi bahwa teori belajar mengkaji tentang aspek-aspek yang terjadi ketika individu melakukan perubahan, sehingga mendeskrip sikan tentang proses dari individu ketika melakukan perubahan. Pengkajian tentang manfaat teori belajar tersebut dalam praktik pembelajaran merupakan cara-cara menggunakan manfaat itu untuk membantu belajar yang efektif. Jadi teori belajar dalam pembelajaran berfungsi untuk menetapkan metode atau cara agar individu melakukan proses belajar. Kerangka pikir yang dihasilkan tersebut digunakan untuk menkondisikan agar individu berproses belajar. Jadi, pengkondisian supaya individu berproses belajar dengan menggunakan kerangka pikir teori belajar adalah yang dimaksud pembelajaran.

Pembelajaran yang imple mentasinya menggunakan kerangka pikir teori belajar sebagai alasan perlunya pengkajian teori belajar. Untuk itu, pembelajaran bagi tunagrahita akan tepat jika dipilih salah satu teori belajar yang sesuai dengan karakteristik tunagrahita. Karakteristik tunagrahita yang lemah dalam berpikir abstrak dan terbatas perkembangan kognitifnya perlu suatu pendekatan pembelajaran atas dasar teori tingkah laku (behavioristik). Salah satu penggagas teori itu adalah Skinner dengan penerapan teori tingkah laku dalam pembelajaran yang disebut modifikasi tingkah laku. Alternatif pendekatan tersebut dipilih dengan mengingat lemahnya tunagrahita ringan pada daya abstraksi dan kognitif, sehingga perlu proses untuk melakukan perubahan dengan pengkondisian adanya penguat (reinforcement), strategi penahapan dengan langkah-langkah yang pendek dan terinci dari sederhana ke langkah yang lebih sulit (shaping), penahapan dengan merantai dimulai dari perilaku yang diharapkan ke perilaku yang telah dikuasai anak (backward chaining), serta penggunaan dorongan dan memudarkan untuk mengurangi dorongan (promting dan fading).
Bentuk-bentuk pengkondisian dari pengembangan modifikasi tingkah laku oleh Skinner dipandang sesuai dengan karakteritik tunagrahita, karena daya abstraksi dan kognitif yang lemah perlu diarahkan untuk melakukan perubahan bertahap sedikit-demi sedikit, berorientasi hasil yang konkrit, dan memotivasi perubahan dari perilaku yang telah dikuasai siswa.

Prinsip-prinsip penyajian materi di atas berkaitan dengan prosedur pembelajaran, sedangkan tahapan atau level materi yang disajikan perlu disesuaikan dengan perkembangan usia mental tunagrahita ringan. Tahapan usia mental tunagrahita perkembangannya lebih rendah dengan usia kronologisnya. Untuk itu, materi yang dibelajarkan perlu disesuaikan dengan tahapan usia mental.

Keterbatasan mental tunagrahita juga berakibat pada kemampuan kognitif. Kemampuan itu masih dioptimalkan jika diberikan intervensi khusus. Eldevik, et.al. (2010) bahwa intervensi khusus pada siswa yang kecerdasan rendah dapat bermanfaat. Intervensi khusus ini terkait taraf usia mental yang dicapai lebih rendah dengan rerata siswa umumnya. Hal itu dalam pembelajaran lebih tepat dengan bermain. Bermain dapat digunakan sebagai sarana belajar matematika, karena disarankan oleh Herman Hudoyo (Wakiman, 1998: 212) sebagai berikut: bawalah suasana kelas yang menyenangkan peserta didik. Suasana yang menyenangkan dapat menimbulkan minat belajar. Untuk menggairahkan suasana itu dengan kegiatan permainan matematika yang sesuai tingkat perkembangan anak. Pendapat itu menekankan bahwa bermain dapat menggairahkan suasana belajar. Bermain digunakan dalam pembelajaran berhitung bagi hambatan tunagrahita agar supaya memotivasi mereka yang sering terhambat. Hambatan motivasi itu dikarenakan penelitian Zigler (Hallahan \& Kauffman, 2003: 121) bahwa tunagrahita lebih sering menghindar dan merasa kesulitan untuk tugas belajar yang berkaitan dengan kognitif. Tugas belajar yang perlu kognitif agar tidak dihindari oleh hambatan mental dan terdorong untuk melakukan belajar perlu dikondisikan belajar dengan bermain.

Bermain sebagai sarana belajar adalah model pembelajaran yang disarankan dalam teori sosio- 
kultural, karena model ini diperkuat oleh Wrigley (2006) dengan penelitian tentang pengalaman dan representasi simbolik yang menjadi fokus dalam penelitian ini adalah mencari manfaat model pendidikan yang progressif dan inklusif. Model ini secara langsung memberi pengalaman belajar, selanjutnya pengalaman itu dikonversi menjadi simbolik untuk menjadi bangunan kognitif siswa. Proses itu dapat terjadi pada siswa jika dalam pembelajaran di kelas digunakan pendekatan progressif dan inklusif. Pendekatan itu dipandang sesuai untuk model proses pengalaman dan representasi simbolik karena siswa diberi kesempatan secara maju membangun pengetahuannya di dalam suasana variasi kelas ketika bermain.

\section{Pembelajaran Pengukuran bagi Tunagrahita Ringan}

Pembelajaran pengukuran bagi tunagrahita ringan ialah mengkondisi kan agar supaya siswa tunagrahita ringan berusaha berlatih mengukur berbagai benda untuk menaksir besaran berat, isi, atau panjang. Pada penelitian ini difokuskan menaksir berat dan isi, karena keduanya saling berhubungan tetapi tidak secara langsung.

Keterbatasan tunagrahita ringan menuntut agar proses pendidikan bagi mereka diarahkan ke pembelajaran keterampilan fungsional (functional skills) sehingga bermanfaat bagi kehidupan siswa tunagrahita. Hal itu ditandaskan oleh Hallahan \& Kauffman (2003: 131) bahwa anak-anak yang kategori retardasi mental/tunagrahita diajarkan akademik untuk kemandirian yang disebut dengan akademik fungsional. Kemandirian itu untuk kehidupan di keluarga, sekolah, di tempat kerja, atau di masyarakat. Keterampilan fungsional tersebut perlu dukungan bidang akademik yang salah satunya adalah kemampuan mengukur.

Kemampuan mengukur adalah salah satu di antara materi pembelajaran matematika. Kemam puan mengukur sebagai salah satu dari bagian keterampilan spesifik dengan menggunakan matematika diperlukan sebagai dasar kemampuan keterampilan aplikasi matematika dan pemecahan masalah dalam kehidupan sehari-hari. Misalnya, mengukur benda yang akan dibentuk atau dibuat, mengukur tempat untuk disesuaikan dengan jumlah penggunanya, mengukur berat untuk dicarikan alat angkatnya dan tempatnya, atau mengukur isi untuk disesuaikan dengan kemampuan alat angkutnya.

Pendekatan pembelajaran mengukur bagi tunagrahita ringan perlu strategi mediational. Mediational menurut Smith, et al. (2002: 254) “A mediator is something that goes between or connects." Maksud pernyataan itu bahwa suatu pengantara adalah sesuatu yang berfungsi jembatan atau penghubung. Selanjutnya, mediator tersebut perlu dilakukan untuk pembelajaran atas dasar penelitian Spitz's.

Penelitian yang dilakukan Spitz's (Smith, et.al. 2002: 254)tersebut men teorikan tentang tahapan input dalam pembelajaran. Bagi tunagrahita lebih sulit, sebab kerugian pada kemampuan mereka untuk mengorganisasi input rangsangan untuk disimpan dan dipanggil lagi jika diperlukan. Pendapat ini menurunkan suatu pernyataan tentang strategi bagi guru untuk meningkatkan kemampuan siswa dalam memasukkan data. Strategi itu dengan pengelompokkan (grouping) dan pengantara (mediation).

Strategi penggunaan mediational untuk meningkatkan kemampuan tunagrahita menata rangsangan yang masuk dengan pengantaran jembatan. Jembatan untuk menguasai penggunaan ukuran tersebut perlu suatu alat simulasi yang secara pengalaman mengukur dapat mengantarai atau mengelompokkan. Salah satunya mengukur berat perlu diantarkan dengan media yang memberi pengalaman variasi berat, variasi berat hubungannya dengan jenis benda, serta variasi berat implikasinya dengan isi.

Berat dan isi perlu dibelajarkan bersamasama, menurut Polloway \& Patton (1993: 320): menjelaskan hubungan pengukuran isi dan berat ada hubungan langsung, namun hubungan itu tidak serta merta secara langsung. Berat tidak dapat diprediksi dari isi, atau isi tidak dapat diprediksi dari berat. Berat merupakan sifat gaya padat suatu benda, sedangkan isi dari mengukur suatu jumlah zat.

Implikasi bagi guru pada permulaan materi pelajaran dimulai menunjukkan benda konkrit yang paling kecil ke benda yang lebih besar, atau sebaliknya. Penjelasan itu meng-isyaratkan bahwa antara isi dan berat ada hubungan tetapi hubungan itu tidak secara langsung. Hubungan 
yang langsung bahwa pertambahan berat suatu jenis benda diikuti pertambahan isinya, namun dibandingkan dengan benda yang bervariasi penambahan volume tidak selalu sama. Tidak selalu sama di dalam penambahan volume dilihat dari beratnya ini yang dimaksud hubungan tidak langsung. Hubungan langsung dan tidak langsung dari sifat pengukuran benda inilah yang menyulitkan konsep pemahaman tunagrahita ringan. Dengan adanya kesulitan itu perlu dilakukan perbaikan pembelajaran dimulai dengan situasi konkrit melalui simulasi permainan, dengan melakukan menimbang berbagai benda seperti kegiatan dalam kehidupan sehari-hari.

Simulasi permainan sebagai dike mukakan oleh Nancy A Neef. et.al. (2003) bahwa praarah seperti mengidentifikasi nilai permulaan, peru bahan nilai, mengoperasikan, dan mendapatkan hasil secara sekuential lebih bermakna pada belajar matematika. Simulasi permainan dengan alat permainan diperoleh proses seperti proses praarah.

Alat permainan itu sebuah timbangan purapura, agar pembelajaran dilakukan dengan senang, tetapi simulasi pengalaman menimbang dan mengukur tetap dilakukan. Untuk simulasi itu menggunakan "Simulasi Permainan Timbangan".

Meilan Zhang, et al. (2010). Meneliti penggunaan "Science Talks" untuk meningkatkan pembelajaran di tingkat taman kanak-kanak. Penggu naan cara itu digunakan alat permainan. Atas dasar penelitian ini alat permainan juga meningkatkan sarana untuk belajar pemecahan masalah. Alat permainan timbangan dalam penelitian ini berupaya anak mampu mengukur berat dan isi benda, juga mengetahui berbagai sifat benda alam yang bervariasi, seperti benda cair, berupa serbuk, dan yang ringan tetapi membutuhkan banyak tempat adalah sifat kodrati di alam dengan pengamatan langsung.

\section{Kerangka Pikir dan Hipotesis}

Siswa tunagrahita ringan memiliki keter-batasan dalam berpikir abstrak, lemah dalam menghubungkan suatu kejadian dengan kejadian lain yang problemnya sama, serta lemahnya mengorganisasikan informasi-informasi yang diperoleh. Kondisi kelemahan itu berakibat kesulitan dalam menghubungkan antara besaran suatu benda pada setiap jenis benda dengan beratnya, karena setiap jenis benda yang berbeda-beda dengan besaran yang sama belum tentu beratnya sama. Kesulitan tersebut berimplikasi dalam penguasaan konsep berat dan isi maupun cara untuk menentukan. Kesulitan itu juga disebabkan karena siswa tunagrahita lebih melihat hubungan berat dan besar benda atas dasar fakta yang dilihat.

Untuk memecahkan problem kognitif pada siswa tunagrahita yang sulit membedakan antara berbagai jenis benda yang besarnya sama belum tentu beratnya sama tersebut, diperlukan suatu proses yang secara nyata dapat dihayati siswa terhadap perubahan berat pada jenis benda yang berbeda-beda. Proses itu dipilih dengan "Simulasi Permainan Timbangan", karena simulasi itu memberi pengalaman cara menimbang untuk perubahan berat. Cara tersebut dipilih, karena penguasaan yang diperlukan jembatan perubahan berat dan cara menentukan. Atas dasar kerangka pikir di atas penelitian ini mengajukan suatu hipotesis tindakan

"bahwa 'Simulasi Permainan Timbangan' mampu memperbaiki dan menjembatani penguasaan peta kognitif siswa tunagrahita tentang konsep perubahan berat dan cara menentukan."

\section{Metode Penelitian}

Penelitian ini menggunakan pendekatan penelitian tindakan kelas dengan satu siklus tindakan. Subjek penelitian siswa di Sekolah Luar Biasa Negeri 2 Yogyakarta (SLB N 2 Yk.) yang dikategorikan tunagrahita ringan dengan perkembangan usia mental 8/9 tahun (bukan usia kronologis) yang ekuivalen dengan kemampuan perkembangan anak normal 8-9 tahun. Subjek sedang dalam tahapan mulai belajar mengukur dan masih kesulitan untuk menghubungkan berat dan isi, belum memiliki konsep tentang perubahan berat dan cara menaksirnya. Subjek yang dipilih sesuai dengan kriteria tersebut, saat penelitian ini berada di tingkat SMP kelas 1 (kelas 7 Pendidikan Dasar) berjumlah 5 orang.

Waktu penelitian dilakukan pada bulan Agustus sampai dengan bulan Oktober 2008. 
Waktu satu bulan untuk persiapan alat, dan dua bulan untuk pelaksanaan. Waktu dua bulan itu dilaksanakan tiap minggu selama 5 jam pelajaran.

Tindakan yang dilakukan dengan pembelajaran melalui bermain timbangan. Alat permainan dirancang oleh guru dari bahan kayu. Di samping itu, dilengkapi beberapa benda yang terbuat dari kayu, gabus dengan berbagai bentuk, warna, dan berbeda besarnya, serta beberapa kelereng (Gambar 1).

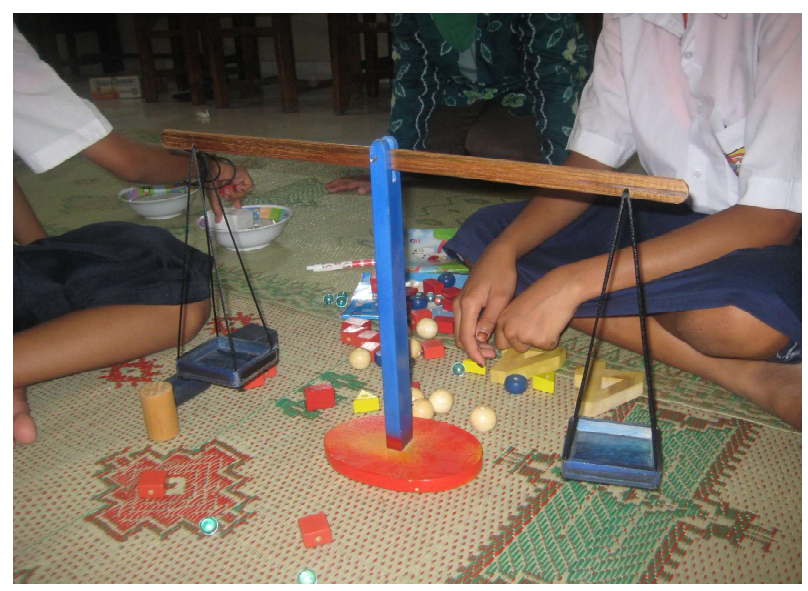

\section{Gambar 1. Pembelajaran melalui Timbangan}

Pelaksanaan tindakan dalam satu siklus dilakukan sebagai berikut.

Pertama, guru mempersiapkan alat permainan dan tempat permainan, siswa diminta membantu menyiapkan alat-alat, kemudian siswa dimotivasi bahwa akan dilakukan bermain bersama-sama; Kedua, guru dan siswa menyusun alat permainan dengan cara berikut. Pada suatu tiang yang ujung atasnya dibuat lekukan guna meletakkan alat pengungkit semacam sekrup yang mengikat sebilah papan horizontal. Papan ini panjang-nya antara kanan dan kiri harus sama/seimbang, sehingga jika diletakkan benda yang beratnya sama juga akan seimbang bentuknya; Ketiga, secara bertahap pada papan itu digunakan untuk menimbang berbagai benda mulai yang jenisnya sama, jenis berbeda, beratnya sama dan beratnya berbeda; Keempat, selanjutnya, juga ditimbang dari benda yang beratnya sama tetapi jenisnya beda, sehingga memberi pengalaman perbedaan volume benda. Hal itu diperoleh dari pengertian bahwa benda yang beratnya sama dan beda jenisnya akan berbeda volumenya. Demikian terus sebaliknya dari volume yang sama, beda jenisnya akan beda beratnya. Pentahapan itu sambil dicatat dan digambar guru dengan skema, agar siswa memperoleh konsep antara perbedaan berat dan volume; Kelima, prosedur itu disajikan secara bervariasi dan pengulangan dengan prosedur yang berbeda-beda sampai dikuasainya konsep berat dan volume. Keenam, setiap prosedur timbangan perlu diurutkan hasilnya, sehingga susunan informasi yang dipelajari siswa tersusun secara kategori atau pengelompokan atas dasar berat sama benda tetapi beda isi, berat beda benda tetapi sama isi, isi sama benda tetapi berat beda, serta isi berat benda sesuai jenis dan variasi isi. Ketujuh, selanjutnya, guru melakukan pengayaan dengan mengajak siswa untuk menimbang berbagai benda yang dibutuhkan dalam kehidupan sehari-hari. Misalnya menimbang teh, kopi, gula pasir, garam, susu, beras, begitu juga siswa mencari pasir dan air.

Cara monitoring tindakan dilakukan menggunakan pedoman observasi tentang tahapan perilaku keterampilan menggunakan alat permainan siswa tunagrahita ringan, dilengkapi wawancara kepada guru untuk konfirmasi tentang objektivitas hasil observasi dan perubahan yang tidak terekam melalui observasi, serta dokumentasi untuk mengetahui status dari siswa tunagrahita ringan yang menjadi subjek penelitian.

Analisis data dilakukan secara deskriptif kualitatif dengan proses menyeleksi, menyederhanakan, meng klasifikasi, memfokuskan, meng organisasi (mengkaitkan gejala) secara sistematis dan logis, serta membuat abstraksi atas simpulan makna hasil analisis. Keberhasilan dalam penelitian tindakan ini jika ditandai oleh: Proses simulasi permainan yang mengaktifkan siswa untuk secara bertahap menimbang berbagai benda dengan variasi jenis, berat, dan isi. Keaktifan siswa membentuk penguasaan konsep tentang menentukan proses perubahan berat dan cara menentukan, serta keterampilan mensetimbangkan alat timbangan.

\section{Hasil dan Pembahasan}

Siswa tunagrahita ringan yang mendapat perlakuan dalam tindakan ini berjumlah lima orang. Siswa tersebut dengan kode As; Ay; Fr; Ib; Nw. Siswa yang berkode As adalah siswa puteri 
kondisinya sedikit mengalami tambahan handicap yaitu tunarungu, namun mudah diajak komunikasi jika lawan komunikasi saling berhadapan lurus dengan muka As. Kemampuannya dalam berhitung sudah sampai taraf menghitung angka sampai ribuan dan sudah mengenal beberapa ukuran jarak, pada kemampuan membedakan berbagai benda sesuai besar dan bentuknya, serta kemungkinan pembandingan beratnya sudah mampu, tetapi belum dapat mengemukakan secara verbal berhubung keterbatasan komuni kasinya. Siswa puteri satunya yang berkode Ay sedikit lancar berbicara dan sudah memiliki kemampuan membedakan bentuk, jenis benda sesuai beratnya, dan sudah memiliki konsep fungsi satuan berat, karena di rumah sering diberi kesempatan berbelanja gula pasir atau beras. Namun, konsep tentang benda yang isinya lebih banyak akan lebih berat masih dimiliki Ay. Fenomenanya ketika Ay ditanya 'antara beras $4 \mathrm{~kg}$ dengan gula pasir 4kg lebih berat mana?' Ay menjawab 'lebih berat beras, karena beras isinya lebih banyak'. Fakta itu menunjukkan masih bingungnya tentang konsep berat yang harus dibuktikan dengan timbangan dan penunjuk satuannya. Ketiga siswa lainnya adalah siswa putera, yang berkode Fr pemahamannya sedikit lebih maju dibanding kedua siswa lainnya, namun konsep benda yang volumenya lebih banyak lebih berat masih terjadi pada pemahaman Fr. Fenomenanya ketika ditanya beberapa benda lebih berat yang mana? Jawabannya masih memilih yang bentuknya lebih besar. Kedua siswa lainnya tidak mampu menjawab, hanya kadang menunjuk dengan cara menimbang dahulu pada alat jungkat-jungkit tersebut. Untuk itu, konsep siswa tentang berat berbagai benda masih perlu diperbaiki. Perbaikan itu dengan tindakan memberi kesempatan kepada siswa berproses secara nyata tentang perubahan berat sesuai jenis-jenis benda.

Proses di dalam tindakan dilakukan sebagai berikut.

Sebelum dilakukan kegiatan menimbang berbagai macam benda, guru menerangkan fungsi dari timbangan jungkat-jungkit yang ada dihadapan siswa, yaitu untuk mengetahui dan membandingkan benda mana yang lebih berat dan benda mana yang lebih ringan. Kegiatan menimbang kemudian dilanjutkan dengan menyeimbangkan keadaan timbangan jungkatjungkit.

Guru membagi siswa menjadi 2 kelompok dan masing-masing kelompok diberikan satu alat timbang neraca dan berbagai macam benda yang akan ditimbang. Benda tersebut adalah gabus, berbagai macam warna, bentuk dan ukuran balok kayu, dan kelereng.

Kegiatan menimbang pertama yaitu menimbang dua benda yang memiliki perbedaan ukuran yang signifikan, seperti tahapan yang tertera pada Tabel 1.

Kegiatan menimbang kedua yaitu menimbang dua benda yang memiliki perbedaan yang tidak signifikan

Tabel 1. Menimbang benda dengan berbeda ukuran yang signifikan.

\begin{tabular}{|c|c|c|}
\hline \multicolumn{2}{|c|}{ Membandingkan berat antara: } & $\begin{array}{c}\text { Hasil } \\
\end{array}$ \\
\hline $\begin{array}{l}\text { Balok kayu } \\
\text { segiempat besar }\end{array}$ & $\begin{array}{l}\text { Balok kayu } \\
\text { segiempat kecil }\end{array}$ & \multirow{5}{*}{$\begin{array}{l}\text { Semua anak bisa menyimpulkan } \\
\text { benda mana yang lebih berat dengan } \\
\text { melihat timbangan jungkat-jungkit, } \\
\text { bahwa benda yang timbangannya } \\
\text { berada di bawah lebih berat dan benda } \\
\text { yang timbangannya di atas lebih } \\
\text { ringan. } \\
\text { Simpulan sementara yang didapat oleh } \\
\text { anak: } \\
\text { Benda yang lebih besar memiliki } \\
\text { timbangan yang lebih berat. } \\
\text { Pada kegiatan ini anak diminta meng- } \\
\text { gambar timbangan dan kegiatan } \\
\text { menimbang serta menuliskan simpulan }\end{array}$} \\
\hline $\begin{array}{l}\text { Balok kayu } \\
\text { segiempat besar }\end{array}$ & $\begin{array}{l}\text { Balok kayu } \\
\text { segitiga kecil }\end{array}$ & \\
\hline $\begin{array}{l}\text { Balok kayu } \\
\text { segiempat besar }\end{array}$ & Balok kayu bulat & \\
\hline $\begin{array}{l}\text { Balok kayu } \\
\text { segiempat besar }\end{array}$ & Balok kayu pipih & \\
\hline $\begin{array}{l}\text { Balok kayu } \\
\text { segiempat besar }\end{array}$ & $\begin{array}{l}\text { Balok } \\
\text { silinder }\end{array}$ & \\
\hline
\end{tabular}


Kegiatan menimbang dilanjutkan dengan menimbang berbagai benda milik siswa, seperti pensil, buku,

Tabel 2. Menimbang benda dengan berbeda ukuran yang tidak signifikan.

\begin{tabular}{|c|c|c|}
\hline \multicolumn{2}{|c|}{ Membandingkan berat antara: } & $\begin{array}{c}\text { Hasil } \\
\end{array}$ \\
\hline $\begin{array}{l}\text { Balok kayu segiempat } \\
\text { kecil }\end{array}$ & Balok kayu segitiga kecil & \multirow{8}{*}{$\begin{array}{l}\text { Semua anak bisa menyimpulkan } \\
\text { benda mana yang lebih berat } \\
\text { dengan melihat timbangan } \\
\text { jungkat-jungkit, bahwa benda } \\
\text { yang timbangannya berada di } \\
\text { bawah lebih berat dan benda } \\
\text { yang timbangannya di atas lebih } \\
\text { ringan. } \\
\text { Dengan dibimbing oleh guru anak } \\
\text { diberikan pemahaman bahwa } \\
\text { benda yang ukurannya hampir } \\
\text { sama belum tentu mempunyai } \\
\text { berat yang sama }\end{array}$} \\
\hline $\begin{array}{l}\text { Balok kayu segiempat } \\
\text { kecil }\end{array}$ & Balok kayu bulat & \\
\hline $\begin{array}{l}\text { Balok kayu segiempat } \\
\text { kecil }\end{array}$ & Balok kayu pipih & \\
\hline Balok kayu segitiga kecil & Balok kayu bulat & \\
\hline Balok kayu segitiga kecil & Balok kayu pipih & \\
\hline Balok kayu bulat & Balok kayu pipih & \\
\hline Balok kayu bulat & Kelereng & \\
\hline Balok berbentuk angka 5 & Balok berbentuk angka 4 & \\
\hline
\end{tabular}

Kegiatan menimbang ketiga adalah menimbang dua benda yang ukurannya sama dari bahan berbeda

Tabel 3. Menimbang dua benda yang ukurannya sama dari bahan berbeda

\begin{tabular}{|c|c|c|}
\hline \multicolumn{2}{|c|}{ Membandingkan berat antara: } & Hasil \\
\hline Balok kayu segiempat & Gabus segiempat & \multirow[b]{3}{*}{$\begin{array}{l}\text { Semua anak bisa menyimpulkan benda } \\
\text { mana yang lebih berat dengan melihat } \\
\text { timbangan jungkat-jungkit, bahwa benda } \\
\text { yang timbangannya berada di bawah lebih } \\
\text { berat dan benda yang timbangannya di atas } \\
\text { lebih ringan. } \\
\text { Dengan dibimbing oleh guru anak diberikan } \\
\text { pemahaman bahwa benda yang ukurannya } \\
\text { sama belum tentu mempunyai berat yang } \\
\text { sama }\end{array}$} \\
\hline Balok kayu segiempat & Busa segiempat & \\
\hline Busa segiempat & Gabus segiempat & \\
\hline
\end{tabular}

Kegiatan menimbang keempat yaitu menimbang benda yang sama

Tabel 4. Menimbang dua benda yang ukurannya sama

\begin{tabular}{|c|c|c|}
\hline \multicolumn{2}{|c|}{ Membandingkan berat antara: } & $\begin{array}{c}\text { Hasil } \\
\end{array}$ \\
\hline $\begin{array}{l}\text { Balok berbentuk angka } \\
5\end{array}$ & $\begin{array}{l}\text { Balok berbentuk angka } \\
5\end{array}$ & \multirow{4}{*}{$\begin{array}{l}\text { Semua anak bisa menyimpulkan } \\
\text { benda mana yang lebih berat dengan } \\
\text { melihat timbangan jungkat-jungkit, } \\
\text { bahwa benda yang timbangannya } \\
\text { berada di bawah lebih berat dan } \\
\text { benda yang timbangannya diatas } \\
\text { lebih ringan. }\end{array}$} \\
\hline $\begin{array}{l}\text { Balok berbentuk angka } \\
4\end{array}$ & $\begin{array}{l}\text { Balok berbentuk angka } \\
4\end{array}$ & \\
\hline Balok kayu silinder & Balok kayu silinder & \\
\hline $\begin{array}{l}\text { Balok kayu segiempat } \\
\text { kecil }\end{array}$ & $\begin{array}{l}\text { Balok kayu segiempat } \\
\text { kecil }\end{array}$ & \\
\hline Balok kayu segitiga kecil & $\begin{array}{l}\text { Balok kayu segitiga } \\
\text { kecil }\end{array}$ & \multirow{6}{*}{$\begin{array}{l}\text { Dengan dibimbing oleh guru anak } \\
\text { diberikan pemahaman bahwa benda } \\
\text { yang ukuran dan bentuknya sama } \\
\text { belum tentu mempunyai berat yang } \\
\text { sama }\end{array}$} \\
\hline Balok kayu pipih & Balok kayu pipih & \\
\hline Balok kayu bulat & Balok kayu Bulat & \\
\hline Kelereng & Kelereng & \\
\hline Busa segiempat & Busa segiempat & \\
\hline Gabus segiempat & Gabus segiempat & \\
\hline
\end{tabular}


hp, uang. Siswa memahami bahwa benda yang lebih berat maka timbangannya akan berada di bawah dan benda lebih ringan maka timbangannya berada di atas.

Selanjutnya, secara bertahap dilakukan menimbang berbagai benda serbuk yang isinya/ volumenya diubah-ubah oleh siswa sendiri. Di sinilah, siswa diberi kesempatan untuk meningkatkan keterampilan menim bang dan menentukan sendiri cara-cara memutuskan berat yang seimbang

Perbaikan penguasaan siswa tunagrahita tentang konsep variasi berat dan isi pada 5 siswa tunagrahita dari masing-masing subjek penelitian berbeda-beda. Perbedaan itu disebabkan juga variasi hambatan kondisi mereka yang juga berbeda-beda. Variasi itu sebagai berikut.

Pertama, subjek Aj dapat menunjukkan tentang benda-benda yang seharusnya lebih berat dengan cara sebelum menimbang di alat dicoba dahulu diletakkan di telapak kanan dan kirinya. Telapak tangannya dirasakan mana yang lebih berat, itulah benda yang lebih berat, jadi dengan perasaan keseimbangan di tangan dapat merasakan benda yang lebih berat. Namun oleh guru dianjurkan untuk membuktikan dengan permainan timbangan sambil mengajak teman putrinya Si As bermain. Ketika mencoba alat itu $A j$ selalu mengajak As mensetimbangkan bagian yang berat sebelah dengan berbagai kepingan permainan yang telah disediakan. Perlakuan $\mathrm{Aj}$ itu mengindikasikan bahwa dia selalu mencoba untuk mencari benda-benda yang lebih berat atau lebih ringan, atau sebaliknya lebih besar dan lebih kecil. Jika ditanya oleh guru mana di antara bendabenda itu yang dapat diperbandingkan lebih berat atau lebih ringan, respon Aj sambil ketawa menunjuk, dan jika guru balik bertanya untuk menegaskan kembali pendapat anak sambil menunjuk posisi permainan timbangan, $\mathrm{Aj}$ menggang guk. Fenomena pada $\mathrm{Aj}$ itu menunjukkan bahwa secara perbuatan langsung sudah menunjukkan penguasaannya tentang perubahan berat dan cara menentukan, tanpa menjelaskan dengan verbal. Hal itu terjadi karena pada umumnya tunagrahita ringan kurang mampu menjelaskan dengan bahasa. Kedua, siswa As walaupun hanya mengikuti yang dilakukan oleh temannya $A j$, jika ditanya guru dan mencoba untuk menimbang sudah menunjukkan mampu melakukan dan mengiyakan dengan mengangguk kesimpulan yang ditegaskan guru. Hal itu dilakukan pada As, karena keterbatasan pendengaran juga menghambat untuk bereaksi dengan penjelasan menggunakan bahasa. Ketiga, siswa Fr, termasuk siswa yang lebih baik kemampuannya sudah dapat menjelaskan dengan kata-kata bahwa tanda benda yang lebih berat jika posisi salah satu kotak samping dari timbangan berada di bawah. Demikian juga sudah mampu menjawab ketika guru mentrasfer kemampuannya ke benda-benda lainnya yang berada di luar pengamatan siswa. Ketika menimbang pasir dan air, dengan terampilnya menstimbangkan kedua posisi timbangan melalui cara menambah/mengkurangkan posisi yang lebih ringan atau lebih berat. Keempat, Siswa Ib dan Nw kemampuannya hampir sama, keduanya juga sudah melakukan penimbangan seperti yang dilakukan oleh temannya.

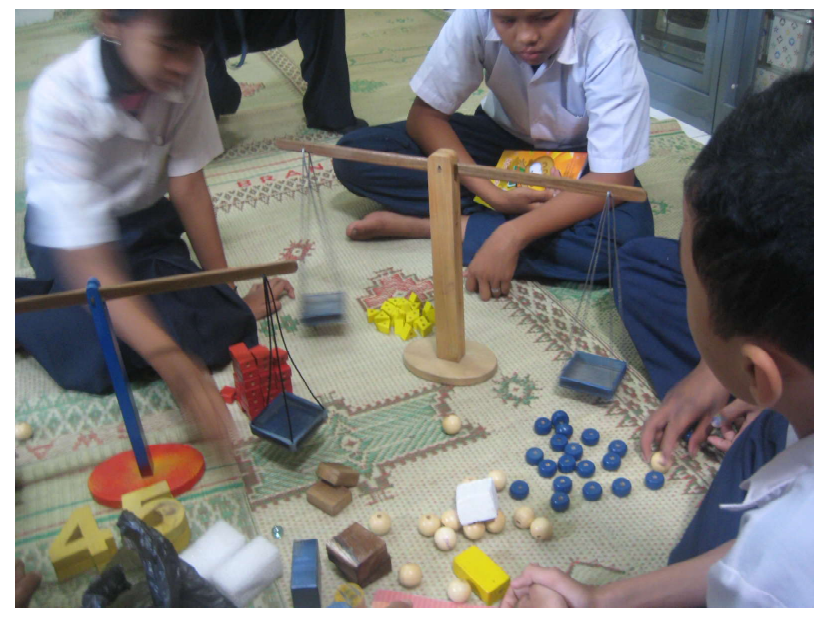

Gambar 2. Ketika siswa berusaha memilih-milih benda untuk dicari keseimbangannya.

Refleksi dilakukan bersama-sama guru untuk mempertimbangkan: pengaruh efektivitas, problem yang timbul, dan keputusan yang perlu dilakukan. Pertama, pengaruh efektivitas penerapan "simulasi permainan timbangan" terhadap kemampuan siswa tunagrahita ringan menunjukkan fungsi perubahan berat dan cara menentukan berat suatu benda. Efektifitas itu diperlihatkan oleh siswa yang bisa menunjukkan benda mana yang lebih berat dan lebih ringan. Demikian juga posisi jungkat-jangkit akan lurus 
bila berat benda setimbang bisa didemonstrasikan oleh siswa. Ketika siswa diminta untuk membuat jungkat-jangkit berada pada posisi setimbang, siswa dapat menambah-kurangkan benda pada jungkat-jangkit tersebut. Kedua, problema yang timbul dari siswa, guru, dan keterbatasan yang terjadi selama tindakan adalah siswa terbatas dalam menyatakan simpulan secara verbal, untuk itu guru harus menolong dengan perbuatan menunjukkan. Problema dari guru bahwa untuk melakukan tindakan pembelajaran belum berani inovasi untuk menstrategikan dengan model lainnya, seperti mengatur benda-benda itu secara berkelompok dan berkategori, lalu siswa diminta menaksirnya tanpa ditimbang dahulu. Keterbatasan dalam tindakan adalah waktu yang lama untuk mempersiapkan alatnya karena kesibukan guru. Ketiga, keputusan yang perlu dilakukan untuk mengatasi problema yang muncul dengan mengubah rancangan tindakan lebih menitikkan beratkan esensi untuk perbaikan penguasaan konsep perubahan berat.

Kriteria keberhasilan ditunjukkan oleh keaktifan siswa untuk secara bertahap menimbang berbagai benda dengan variasi jenis, berat, dan isi. Keaktifan siswa membentuk penguasaan tentang menentukan proses perubahan berat dan cara menentukan, serta keterampilan mensetimbangkan alat timbangan. Kriteria yang telah ditetapkan tersebut telah tercapai seperti yang ditunjukkan oleh hasil tindakan. Dengan demikian, penelitian ini telah mencapai sesuai kriteria keberhasilan yang disebutkan di atas. Hal itu terdukung oleh faktor-faktor pendekatan pembelajaran yang dilakukan guru sudah menyesuaikan dengan karakteristik siswa dan usia mental siswa yang menjadi subjek penelitian.

Penguasaan siswa tunagrahita ringan terhadap konsep pengukuran berat dan isi meliputi: benda yang volumenya lebih banyak belum tentu lebih berat; untuk mngetahui berat suatu benda harus dilakukan penimbangan; dan konsep setimbang juga sudah ditunjukkan dengan melakukan usaha menambah atau mengurangi dari beban yang ditimbang di Neraca timbang permainan jungkat-jungkit.

Penguasaan konsep setimbang tersebut adalah belajar pengukuran terhadap benda. Pengukuran terhadap benda ini belum menyang- kut pada hitungan dengan berbagai ukuran berat pada timbangan. Penguasaan konsep ini baru taraf pra-mengukur untuk bidang matematika dan mengetahui berbagai sifat benda atas dasar hubungan berat dan isi dalam ilmu pengetahuan alam. Jadi simulasi ini sebagai dasar untuk mengintegrasikan dua bidang pelajaran dalam kehidupan sehari-hari.

Perbaikan konsep itu dapat dilakukan secara bertahap dan pengklasifikasian: a) benda yang berbeda signifikan, b) benda yang berbeda tidak signifikan, c) berat sama bahan berbeda. d. benda sama dengan berat berbeda. Pentahapan dan pengklasifikasian tersebut mendasari pada pendapat penelitian Spitz's dalam (Smith, et al., 2002: 254) yang menteorikan tentang tahapan input dalam pembelajaran. Bagi tunagrahita lebih sulit, sebab kerugian pada kemampuan mereka untuk mengorganisasi input rangsangan untuk disimpan dan dipanggil lagi jika diperlukan. Pendapat ini menurunkan suatu pernyataan tentang strategi bagi guru untuk meningkatkan kemampuan siswa dalam memasukkan data. Strategi itu dengan pengelompokkan (grouping) dan pengantara (mediation).

Strategi penggunaan mediational untuk meningkatkan kemampuan tunagrahita menata rangsangan yang masuk dengan pengantaran jembatan. Jembatan untuk menguasai penggunaan ukuran tersebut perlu suatu alat simulasi yang secara pengalaman mengukur dapat mengantarai atau mengelompokkan. Salah satunya mengukur berat perlu diantarkan dengan media yang memberi pengalaman variasi berat, variasi berat hubungannya dengan jenis benda, serta variasi berat implikasinya dengan isi.

Konsep pengantaran atau jembatan ini juga dilakukan oleh guru dengan memodifikasi penyusunan rancangan pembelajaran. Modifikasi dengan cara pembelajaran tentang simulasi permainan jungkat-jungkit ini sebagai jembatan menuju pembelajaran tentang konsep pengukuran satuan berat selanjutnya.

Efektivitas untuk pembentukan peta kognitif tunagrahita ringan tentang konsep ukuran berat dan isi sebagai berikut. Pembelajaran dikemas dalam bentuk permainan sehingga terjadi perubahan suasana belajar. Siswa menjadi senang belajar dan tidak terbebani oleh berpikir 
kognitif. Pembelajaran yang dikemas dalam bentuk permainan juga meningkatkan motivasi siswa sehingga siswa lebih engage dalam kegiatan belajarnya yang pada akhirnya akan berpengaruh terhadap penguasaan keterampilan yang diharapkan. Berdasarkan penelitian yang dilakukan oleh Zigler (Hallahan \& Kauffman, 2003: 121) bahwa tunagrahita lebih sering menghindar dan merasa kesulitan untuk tugas belajar yang berkaitan dengan kognitif, sehingga kegiatan yang menyenangkan seperti permainan akan lebih efektif dalam menanamkan suatu konsep yang memerlukan kognitif.

Dengan metode permainan, siswa juga akan lebih aktif berpartisipasi dalam kegiatan pembelajaran karena bermain dapat membangkitkan rasa senang siswa sehingga siswa lebih menghayati proses perubahan tentang berat secara nyata. Untuk itu, efektivitas dari pembelajaran dengan simulasi permainan timbangan terletak pada telah terbentuknya peta kognitif siswa tunagrahita ringan yang meliputi; (a) benda yang volumenya lebih banyak belum tentu lebih berat; (b) untuk mengetahui berat suatu benda harus dilakukan penimbangan; (c) konsep setimbang juga sudah ditunjukkan oleh mereka dengan melakukan usaha menambah atau mengurangi beban yang ditimbang di neraca permainan timbangan.

\section{Simpulan dan Saran}

\section{Simpulan}

Penelitian tindakan kelas ini hasilnya dapat disimpulan sebagai berikut. Pembelajaran dengan simulasi permainan timbangan dapat membentuk penguasaan tunagrahita ringan tentang konsep pengukuran berat dan cara menentukan dengan proses siswa bermain timbangan yang pura-pura tersebut dari benda perbedaan ukuran signifikan ke perbedaan berat yang tidak signifikan. Selanjutnya, menimbang benda yang ukurannya sama dari bahan berbeda secara bertahap. Simulasi Permainan Timbangan ini efektif untuk pembelajaran pembentukan konsep ukuran berat dan isi bagi tunagrahita ringan. Efektif itu telah terbentuknya peta kognitif siswa tunagrahita yang berbentuk pengetahuan tentang proses perubahan berat-ringannya suatu benda harus melalui proses pengukuran dengan menggunakan alat timbang. Demikian juga, di bidang pengetahuan alam mengetahui berbagai sifat benda tentang berat dan isinya yang diketemukan sehari-hari.

\section{Saran}

Simulasi permainan timbangan dapat diimplementasikan untuk pembentukan peta kognitif tunagrahita ringan, khususnya konsep tentang pengukuran berat dan isi dalam pembelajaran berhitung dan terintegrasi dengan Ilmu Pengetahuan Alam. Untuk itu, perlu dilanjutkan dengan lebih menstandardisasikan dan menyempurnakan alat peraga yang digunakan, serta kemampuan kognitif tunagrahita dapat dibina melalui pembelajaran yang distrategikan secara grouping.

\section{Pustaka Acuan}

Astati. 2001. Persiapan pekerjaan penyandang tunagrahita. Bandung: CV. Pandawa.

Dimyati \& Mudjiono. 2002. Belajar dan pembelajaran. Jakarta: Rineka Cipta.

Eldevik, S., Jahr, E., Eikeseth, S., Hastings, R., \& Hughes, C. 2010. Cognitive and Adaptive Behavior Outcomes of Behavioral Intervention for Young Children With Intellectual Disability. Behavior Modification, 34(1), 16. Retrieved June 11, 2010, from ProQuest Education Journals. (Document ID: 1943253901).

Hallahan, DP. \& Kauffman, JM. 2003. Exceptional Learner:Introduction to Special Education. Boston: Pearson Education, Inc.

Meilan Zhang, Susan Passalacqua, Mary Lundeberg, Matthew J Koehler. 2010. "Science Talks" in Kindergarten Classrooms: Improving Classroom Practice Through Collaborative Action Research. Journal of Science Teacher Education, 21(2), 161-179. Retrieved June 11, 2010, from 
ProQuest Education Journals. (Document ID: 1995142751).

Nancy A Neef, Diane E Nelles, Brian A Iwata, Terry J Page. 2003. Analysis of precurrent skills in solving mathematics story problems. Journal of Applied Behavior Analysis. Lawrence: Vol. 36, Iss. 1; pg. 21.

Oliver. M.A.J. \& Williams. E.E. 2005, Vol 20, No.2. Teaching the Mentally Handicapped Child: Challenges Teachers are Facing. Diambil dari www.Internationaljournalofspecialeducation.com. pada tanggal 4 Februari 2006.

Polloway, E. A. \& Patton, J. R. 1993. Strategies for teaching learners with special needs. $5^{\text {th }}$ ed. New York: Macmillan Publishing Company.

Smith, M. B., Ittenbach, R. F. \& Patton, J.R. 2002. Mental retardation. $6^{\text {th }}$ ed. New Jersey: Merrill Prentice Hall.

Toeti Soekamto \& Udin Saripudin Winatasaputra. 1994. Teori belajar dan model-model pembelajaran. Jakarta: Debdikbud, DIKTI.

Wakiman. 1998. Menumbuhkan kesenangan belajar matematika melalui permainan. Jurnal Kependidikan. Nomor 2, tahun XXXVIII. 1998. Yogyakarta: Lembaga Penelitian IKIP YOGYAKARTA.

Wrigley. 2006. In Search of Inclusive Pedagogies: The Role of Experience and Symbolic Representation in Cognition. International Journal of Pedagogies and Learning. 2(1).114-128. Diambil dari (Terry, Wriley@ed.ac.uk). tanggal 20 Desember 2008 